\title{
Description of Kavayva, gen. nov., (Chalcidoidea, Eurytomidae) and two new species associated with Guarea (Meliaceae), and a review of New World eurytomids associated with seeds
}

\author{
Y. Miles Zhang', Michael W. Gates', Rogerio Silvestre ${ }^{2,3}$, Manuela Scarpa ${ }^{3}$
}

I Systematic Entomology Laboratory, Agricultural Research Service, U.S. Department of Agriculture, clo National Museum of Natural History, Smithsonian Institution, P.O. Box 37012, MRC-168, Washington, DC 20013-7012, USA 2 Hymenoptera Ecology Laboratory- Hecolab, Universidade Federal da Grande DouradosUFGD. Rod. Dourados Itahum km 12, Cidade Universitária, 79804-970, Dourados, Mato Grosso do Sul, Brazil 3 Graduate Program in Entomology and Biodiversity Conservation - UFGD, Dourados, Brazil

Corresponding author: Michael W. Gates (Michael.Gates@usda.gov)

Academic editor: Petr Janšta | Received 8 July 2021 | Accepted 3 September 2021 | Published 29 October 2021

http://zoobank.org/0B892FB9-A903-44C4-9B5D-4AF6D76E48A2

Citation: Zhang YM, Gates MW, Silvestre R, Scarpa M (2021) Description of Kavayva, gen. nov., (Chalcidoidea, Eurytomidae) and two new species associated with Guarea (Meliaceae), and a review of New World eurytomids associated with seeds. Journal of Hymenoptera Research 86: 101-121. https://doi.org/10.3897/jhr.86.71309

\begin{abstract}
Kavayva Zhang, Silvestre \& Gates, gen. nov., and two species are described from the Neotropics, Kavayva bodoquenensis Zhang, Silvestre \& Gates, sp. nov., and Kavayva davidsmithi, Zhang \& Gates, sp. nov. Specimens of the new species were collected independently during separate research efforts in Peru and Brazil, reared from the seeds of Guarea F. Allam ex L. (Meliaceae), which represents a new host plant family for Eurytomidae. A differential diagnosis of the New World seed-feeding eurytomids is also provided.
\end{abstract}

\section{Keywords}

Neotropical region, Phytophagy, seed chalcids

Copyright Y.Miles Zhang et al. This is an open access article distributed under the terms of the Creative Commons Attribution License (CC BY 4.0), which permits unrestricted use, distribution, and reproduction in any medium, provided the original author and source are credited. 


\section{Introduction}

The Eurytomidae is one of the smaller family of Chalcidoidea, and the majority of their larvae feed endophytically as seed eaters, gall formers, or as parasitoids of phytophagous insects (Lotfalizadeh et al. 2007). Most seed-feeders of cultivated plants are considered as pest insects, which can be accidentally transported to new regions given their cryptic lifestyle.

In the Neotropics, three genera have been recorded to be associated with seeds. The most commonly encountered genus is Bephratelloides Girault, which are known seed feeders of Annonaceae (Grissell and Schauff 1990; Grissell and Foster 1996; Chang 1998). Bephratelloides abulus Grissell and Foster was erroneously reported to be associated with Diospyros digyna Jacq. (Ebenaceae), but was later shown to be Prodecatoma diospyri Muesebeck (Castañeda-Vildózola et al. 2011; Ruiz-Montiel et al. 2021). Although not a major pest, Bephratelloides have been documented in various species of custard apple grown for human consumption, such as atemoya, cherimola and others in Florida (USA), Mexico and Brazil (Peña and Bennett 1995; Moura et al. 2006; Hernández-Fuentes et al. 2008; Castañeda-Vildózola et al. 2010). The genus is also commonly intercepted at US ports of entry and submitted to the Systematic Entomology Lab for identification, with 634 specimens submitted over the past 25 years (M. Touchet, pers. comm.). Three species of Bephratelloides were included in Lotfalizadeh et al. (2007) as part of the morphological phylogenetic analysis of Eurytominae, and the genus was weakly recovered by homoplastic characters including bilobed clypeus and relatively long postgenal bridge.

Prodecatoma Ashmead have been recorded from South America, Africa, and Asia, although the genus is likely not monophyletic (DalMolin et al. 2004). Lotfalizadeh et al. (2007) redefined the genus in a restricted sense to contain only the Neotropical phytophagous species, which is supported by the following morphological characteristics: lower face strigose with a median carina continued on intertorular space; intertorular space raised into a broadly laminate and discoid projection continuing dorsally on the scrobal depression; and prepectus with subventral carinae distinctly diverging anteriorly. This group now contains gall formers and inquilines on Araceae, Dipterocarpaceae, Ebenaceae, Fabaceae, Liliaceae, Myrtaceae, Meliaceae, Rubiaceae, Sabiaceae and Vitaceae (DalMolin et al. 2004; Lotfalizadeh et al. 2007; Ruiz-Montiel et al. 2021).

Paradecatoma Masi is a small genus restricted to Afrotropical region, with a single described species Paradecatoma bannensis Masi from the pyrene/drupe of Cordia africana Lam. (Boraginaceae) (Yirgu and Delvare 2019), and at least three undescribed species associated with seeds of Combretum glutinosum Perr. ex DC. and Terminalia macroptera Guill. $\&$ Perr. (Combretaceae) (Lotfalizadeh et al. 2007). All four species of Paradecatoma were included in the Lotfalizadeh et al. (2007) study, and the genus was weakly recovered with the following characters: narrow intertorular space and strongly raised margin on antennal toruli, lateral foraminal plate not delimited, and subforaminal bridge with vestigial median strip. Eurytoma weraubia Gates \& Cascante-Marin (2004) is a phytophagous Neotropical species associated with floral buds of Werauhia gladioliflora (Wendl.) (Bromeliaceae), Lotfalizadeh et al. (2007) suggested that E. werauhia probably belongs to Paradecatoma Masi, which would greatly expand the biogeographic range of the genus. However, ongoing phylogenomic analysis suggests E. werauhia is actually a new genus (Zhang et al. in prep). 
Table I. Morphological comparison of comparison of New World Eurytomidae associated with seeds.

\begin{tabular}{|c|c|c|c|c|}
\hline & Bephratelloides & Prodecatoma & Eurytoma weraubia & Kavayva \\
\hline $\begin{array}{l}\text { Intertorular } \\
\text { space }\end{array}$ & $\begin{array}{c}\text { minute, rounded projection } \\
\text { with tip truncate }\end{array}$ & $\begin{array}{c}\text { projection thin, long and } \\
\text { narrow, pointy }\end{array}$ & $\begin{array}{c}\text { projection thin, long and } \\
\text { narrow, pointy }\end{array}$ & no projection \\
\hline $\begin{array}{l}\text { Frontal } \\
\text { depression }\end{array}$ & $\begin{array}{c}\text { wider ventrally, slightly } \\
\text { broadening towards } \\
\text { toruli, anterior ocellus not } \\
\text { included }\end{array}$ & $\begin{array}{l}\text { wider ventrally, slightly } \\
\text { broadening towards toruli, } \\
\text { anterior ocellus partially } \\
\text { included }\end{array}$ & $\begin{array}{l}\text { wider ventrally, slightly } \\
\text { broadening towards } \\
\text { toruli, anterior ocellus not } \\
\text { included }\end{array}$ & $\begin{array}{c}\text { wider dorsally, narrowing } \\
\text { towards toruli, anterior } \\
\text { ocellus not included }\end{array}$ \\
\hline Ventral plaque & no & in some males & no & in all males, some females \\
\hline Forewing & stigmated & not stigmated & not stigmated & $\begin{array}{l}\text { thickened in males, } \\
\text { stigmated }\end{array}$ \\
\hline Procoxa & striate-rugose & striate & with oblique groove & smooth, with lamella \\
\hline Propodeum & $\begin{array}{c}\text { coarsely sculptured laterally, } \\
\text { broad, median furrow } \\
\text { present or absent }\end{array}$ & $\begin{array}{c}\text { coarsely sculptured laterally, } \\
\text { broad, no median furrow }\end{array}$ & $\begin{array}{l}\text { broad, flat, median furrow } \\
\text { areolate, slightly narrowing }\end{array}$ & broad, flat, smooth \\
\hline
\end{tabular}

The research presented here is based on specimens collected independently during separate research efforts in Peru, Panama, and Brazil, reared from the seeds of Guarea F. Allam ex L. (Meliaceae), which represents a new host plant family for Eurytomidae (Fig. 1). The goal of this study is to describe the new genus Kavayva and the two new species, and provide an overview of the generic concepts of New World seed-feeding eurytomids.

\section{Materials and methods}

\section{Field collection}

Guarea kunthiana A. Juss. (Meliaceae), is a perennial tree of secondary to late climax communities. Its height reaches up to $20 \mathrm{~m}$ and its diameter up to $60 \mathrm{~cm}$, and it occurs commonly in semi-deciduous forests in Central and South American (Pennington and Clarkson 2013). The common name in Brazil is "Figo do Mato" (Lorenzi 2002). The unisexual flowers secrete nectar and are pollinated by Coleoptera and Lepidoptera, with seed dispersal by birds and rodents (Wenny 1999). Flowering occurs from November to December, but may occur sporadically throughout the year (Souza et al. 2002).

Fruits were collected in a semi-deciduous Atlantic Forest (Fig. 2) at Serra da Bodoquena, Bonito, Mato Grosso do Sul, Brazil, near the Taquaral river $\left(21^{\circ} 06^{\prime} 56^{\prime \prime}\right.$, $\left.56^{\circ} 38^{\prime} 24^{\prime \prime W}\right)$, and the Boqueirão farm $\left(21^{\circ} 07^{\prime} 31.8^{\prime \prime} \mathrm{S}, 56^{\circ} 43^{\prime} 20.9^{\prime \prime} \mathrm{W}\right)$, at altitudes of $582 \mathrm{~m}$ and $540 \mathrm{~m}$ above sea level, respectively. There were four seasonal samplings in May and December 2015, and in February and May 2016. The fruits were collected from trees in linear transects 1000 meters long, with a perpendicular distance of 5 meters on either side, when allowed by the topography of the area, totaling 10,000 square meters ( $1 \mathrm{ha})$.

The fruits were collected manually with scissors (Fig. 3), the quantity varied according to the availability on each plant. They were individually placed, where possible, in plastic pots containing sterilized sand as a substrate for pupal burial, with small holes in the lid for air circulation (Fig. 4). Pots were observed daily and parasitoids that 


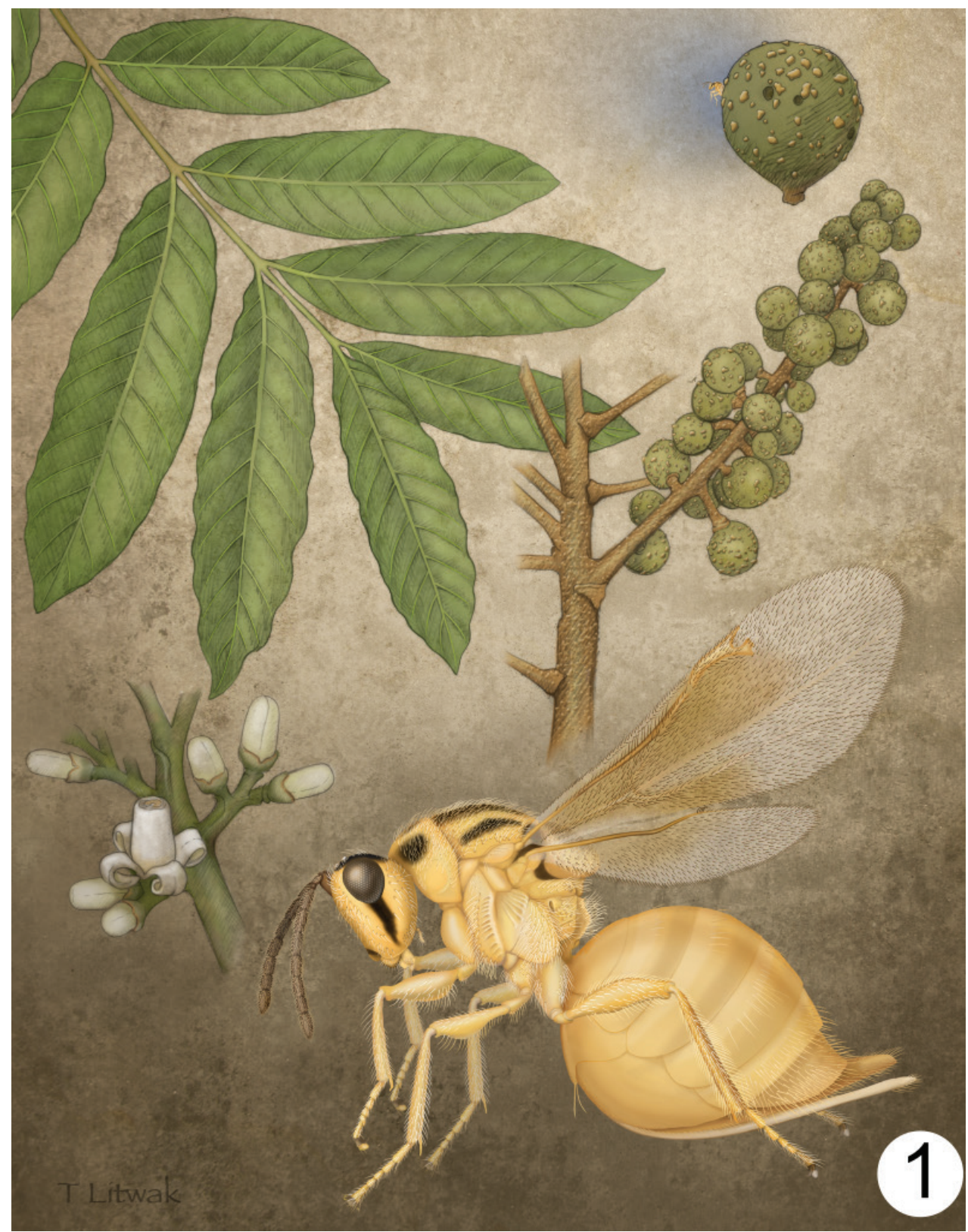

Figure I. Illustration of Kavayva davidsmithi with its host plant, Guarea guidonia (Meliaceae). The upper right shows the emergence holes from the fruit. Illustrated by Taina Litwak.

emerged from the fruits kept alive six hours to fix the chromatic patterns, and then placed in ethanol and frozen.

Voucher species were incorporated into the Hymenoptera collection (HyMB) of the Museum of Biodiversity (MuBio) of the Federal University of Grande Dourados 


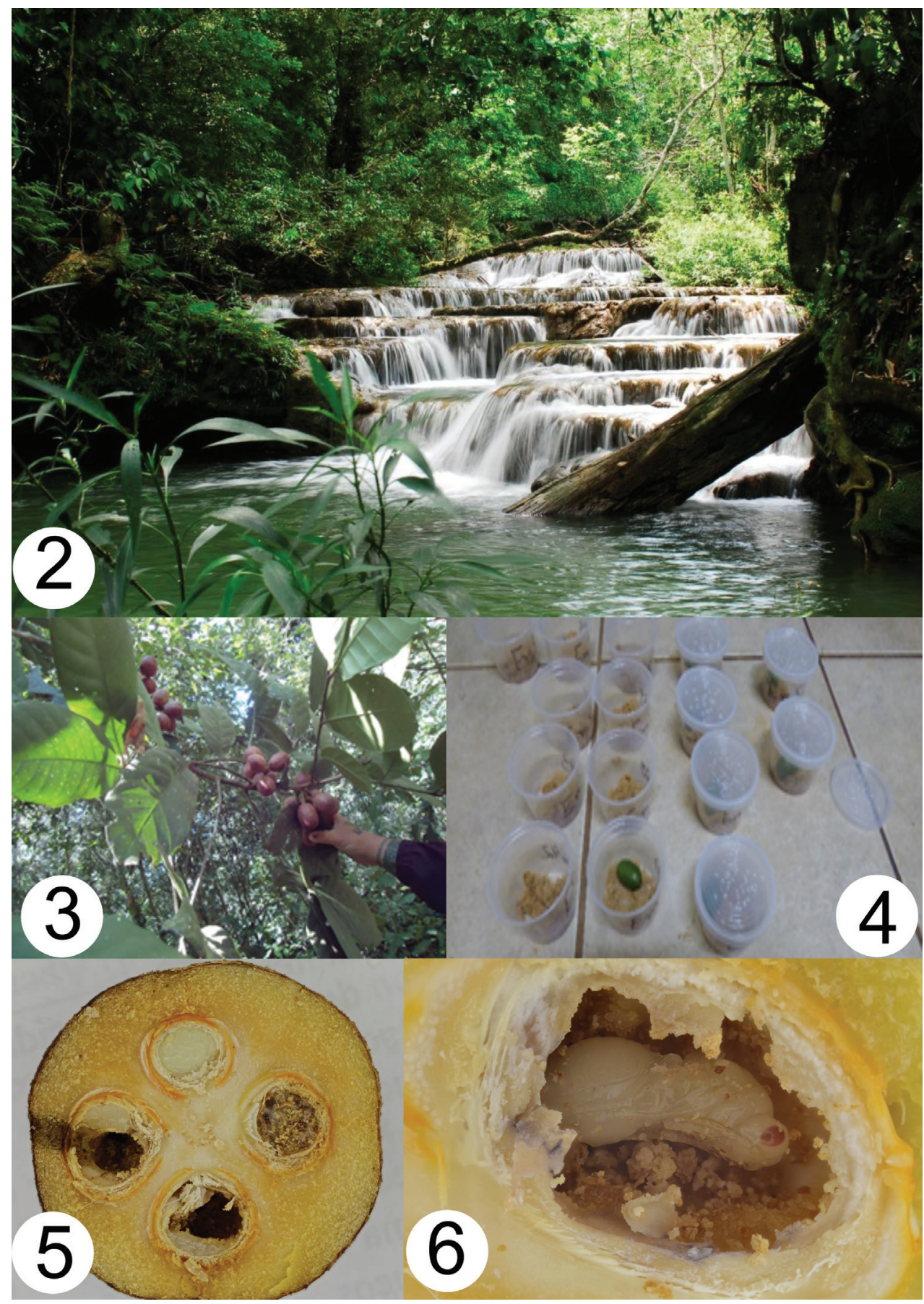

Figure 2-6. Collection of Kavayva bodoquenensis $\mathbf{2}$ semi-deciduous forest along the Taquaral river, Serra da Bodoquena, Brazil $\mathbf{3}$ fruits of Guarea kuntiana on tree $\mathbf{4}$ individualized plastic pots with sterilized sand $\mathbf{5}$ seed damage by $K$. bodoquenensis $\mathbf{6}$ pupa of $K$. bodoquenensis. Photo I by Paulo Robson de Souza $\mathbf{3 , 4}$ by Manuela Scarpa $\mathbf{5 , 6}$ by Bhrenno Trad. 
(UFGD), Dourados-MS, Brazil. For the species of trees from which fruits are sampled, vouchers were collected, and sent to the Botanic Sector of the UFGD to be identified by Dr. Zefa Valdevina Pereira and incorporated into the MuBio Herbarium.

\section{Molecular protocol}

Specimens were extracted, amplified, and sequenced at the Laboratories of Analytical Biology (LAB) at the Smithsonian Institution's National Museum of Natural History (NMNH, Washington, DC, USA). A single specimen of $K$. bodoquenensis was destructively sampled using the DNeasyTM Tissue Kit protocol (Qiagen, Valencia, CA, USA). Fragments of mtDNA COI were amplified using LCO1490 5'-GGTCAACAAATCATAAAGATATTGG-3' and HCO2198 5'-TAAACTTCAGGGTGACCAAAAAATCA-3' (Folmer et al. 1994). PCR was performed using approximately $2 \mu \mathrm{l}$ DNA extract, $1.25 \mu \mathrm{L} 10 \times$ Buffer, $1 \mu \mathrm{l}$ dNTP, $1 \mu \mathrm{l}$ of each primer, 1 unit of Taq DNA polymerase (TaKaRa Bio, Mountain View, CA, USA), and purified water for a final volume of $25 \mu \mathrm{l}$. Amplicons of COI were generated with an initial denaturation of $1 \mathrm{~min}$ at $95^{\circ} \mathrm{C}$, followed by 35 cycles at $95^{\circ} \mathrm{C}$ for $15 \mathrm{~s}, 49^{\circ} \mathrm{C}$ for $15 \mathrm{~s}$ and $72{ }^{\circ} \mathrm{C}$ for $45 \mathrm{~s}$, and a final elongation period of $4 \mathrm{~min}$ at $72{ }^{\circ} \mathrm{C}$. Sequencing was conducted using an ABI 3730xl DNA sequencer following the manufacturer's instructions. Contigs were assembled and edited using Geneious Prime v2021.1. DNA sequences were then compared with all available sequences in the Basic Local Alignment Search Tool (BLAST) for nucleotides in GenBank.

\section{Imaging}

Ethanol-preserved specimens were dehydrated through increasing concentrations of ethanol, and transferred to hexamethyldisilazane (HMDS) (Heraty and Hawks 1998) before point-mounting. MWG identified the specimens using a Leica M205C stereomicroscope with 10X oculars and a Leica LED ring light source for point-mounted specimen observation. We took scanning electron microscope (SEM) images with a Hitachi TM3000 (Tungsten source). Body parts of disarticulated specimens were adhered to a 12.7 X $3.2 \mathrm{~mm}$ Leica/Cambridge aluminum SEM stub by a carbon adhesive tab (Electron Microscopy Sciences, \#77825-12). Stub-mounted specimens were sputter coated with gold-palladium using a Cressington Scientific 108 Auto from multiple angles to ensure complete coverage $(-20-30 \mathrm{~nm}$ coating). Habitus images were obtained using a Visionary Digital imaging system. The system consists of a Canon EOS 5D Mark II digital SLR camera with a $65 \mathrm{~mm}$ macro lens. A Dynalite MP8 power pack and lights provided illumination. Image capture software was Visionary Digital's proprietary application with images saved as TIF with the RAW conversion occurring in Canon Digital Photo Professional software. Image stacks were mounted with Helicon Focus 6.2.2. Image editing was done in Adobe Photoshop and plate layout in Adobe Illustrator. The painting (Fig. 1) was made from pinned and live insect specimens, plant herbarium sheets and photographs. Additional structural details of 
the insects were obtained from SEM photographs. The final image was painted using Adobe Photoshop.

All species identifications were corroborated by comparison with authoritatively identified specimens in the Smithsonian National Museum of Natural History. Terminologies used for surface sculptures follow Harris (1979), while the morphology follows Gibson (1997), Lotfalizadeh et al. (2007), and Gates and Pérez-Lachaud (2012) for adults, and Short (1952), Roskam (1982), and Henneicke et al. (1992) for larvae. Abbreviations for museums are: MUSM - Natural History Museum of the San Marcos University, UFGD, Museum of Biodiversity of the Federal University of Grande Dourados, Dourados-MS, Brazil, and USNM - United States National Museum of Natural History, Washington, D.C., USA.

\section{Results}

The $K$. bodoquenensis adults emerged between May 8-29, 2016. Twenty-eight fruits were collected with a combined weight of $584.30 \mathrm{~g}$ (average $=20.87 \mathrm{~g}$ ). The fruits were soft carmine color, with fibrous texture, without pulp, containing 4-8 almond-shaped seeds (Fig. 5). On average, $25 \%$ of the seeds were parasitized. Only one hole per seed was observed to indicate emergence of wasps. A total of 32 individuals emerged from seeds in the laboratory (Fig. 6), 20 females and 12 males, with a sex ratio of $0.6 \mathrm{~m} / \mathrm{f}$. An unidentified adult female Sesiidae (Lepidoptera) emerged from one of the seeds. The COI sequence (676 bp, GenBank Accession \# MZ483873) did not match any known species.

\section{Kavayva Zhang, Silvestre, \& Gates, gen. nov.}

http://zoobank.org/E9334690-6851-4440-8244-986B9BC45405

Figs $1,7-27$

Type species. Kavayva bodoquenensis Zhang, Silvestre, Gates.

Diagnosis. Kavayva can be distinguished from other eurytomid genera by the following combination of characters - presence of ventral plaque of scape form a projection on the inner face below the attachment to pedicel in males (Kavayva bodoquenensis, Fig. 13) or both sexes (Kavayva davidsmithi, Fig. 26), F1 of antenna cylindrical and not constricted (Fig. 12), presence of deep black line along the malar sulcus (Fig. 25), middle of propodeum completely glabrous and smooth (Fig. 15), and associated with seeds of Guarea (Meliaceae).

Description. Female body length 6.5-10 mm, male 6.5-9.4 mm.

Color. Mostly yellow, black along malar sulcus, with brown infuscation or black bands on the dorsal mesosoma.

Head. Quadrate with rounded corners, 2.4-2.5x as wide as long in dorsal view (Figs 9, 25), areolate-rugose with setae. Lower face weakly strigose, clypeus bilobed, mandible tridentate, supraclypeal area smooth, slightly concave, extending to the toruli 


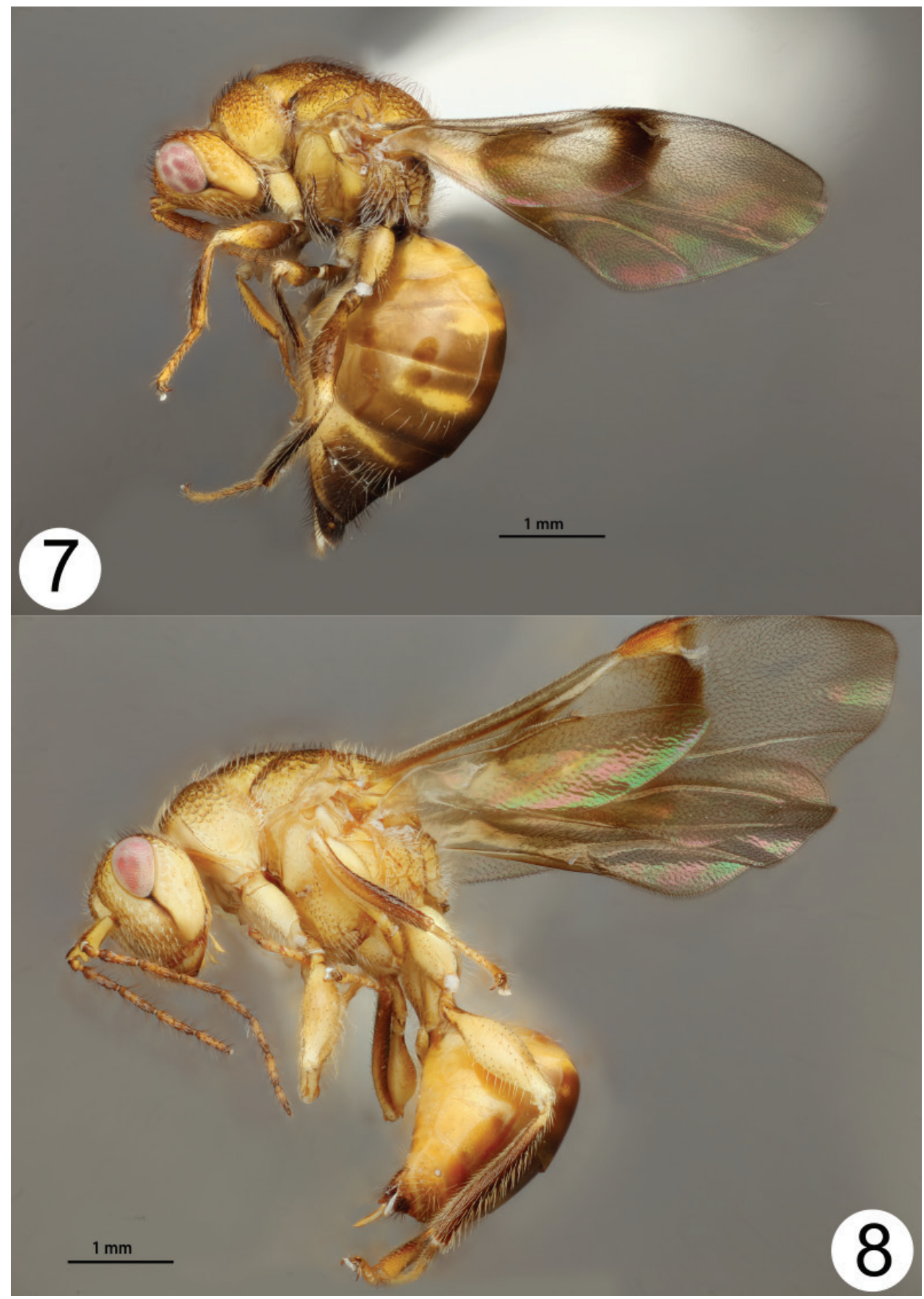

Figure 7-8. Lateral habitus of Kavayva bodoquenensis $\mathbf{7}$ female $\mathbf{8}$ male. Photos by Cecilia Escobar. 


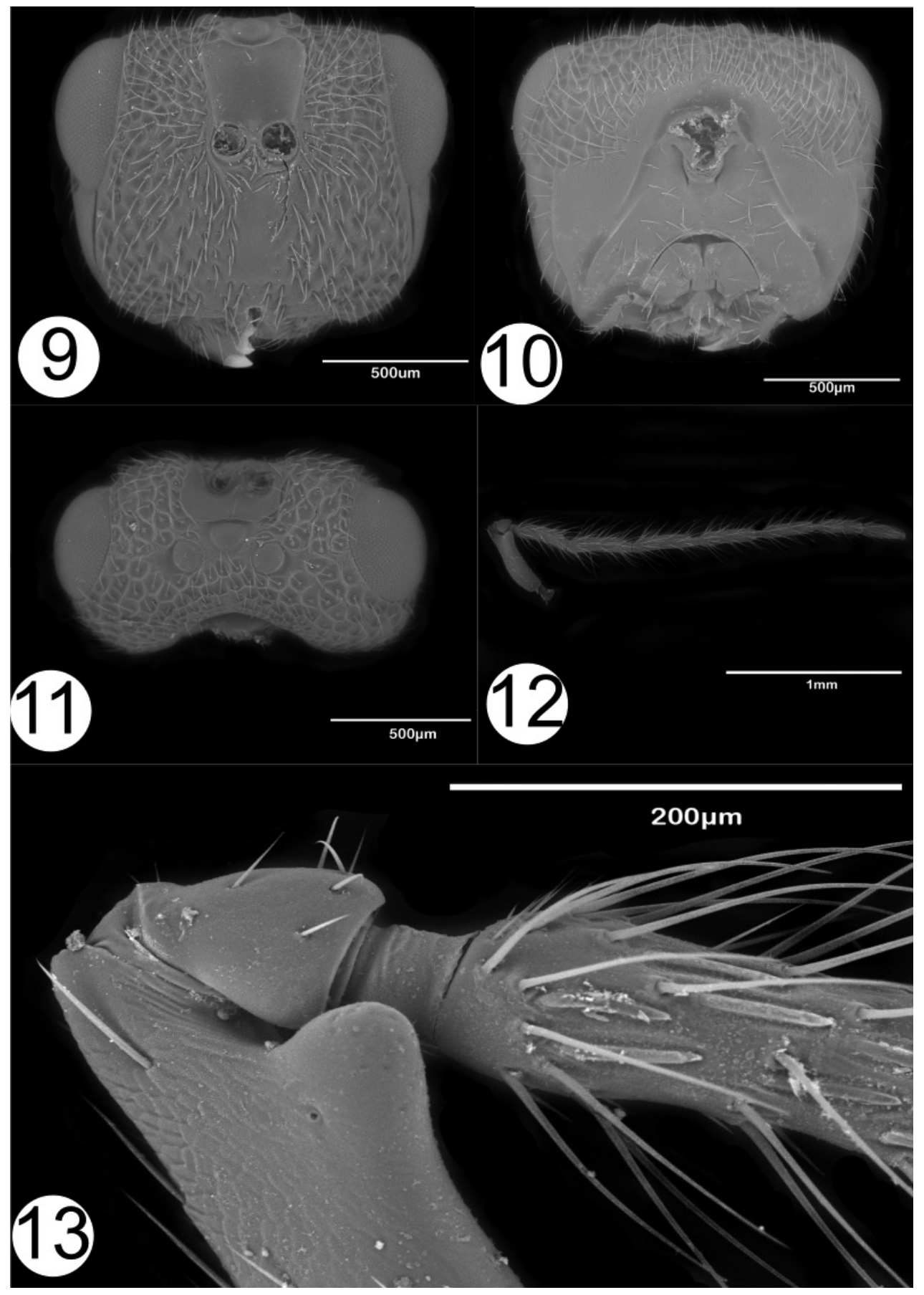

Figure 9-13. Kavayva bodoquenensis 9 frontal view of head $\mathbf{I} \mathbf{0}$ ventral view of head I I dorsal view of head I $\mathbf{2}$ male antenna $\mathbf{I} \mathbf{3}$ close up of ventral plaque on antennal scape. 


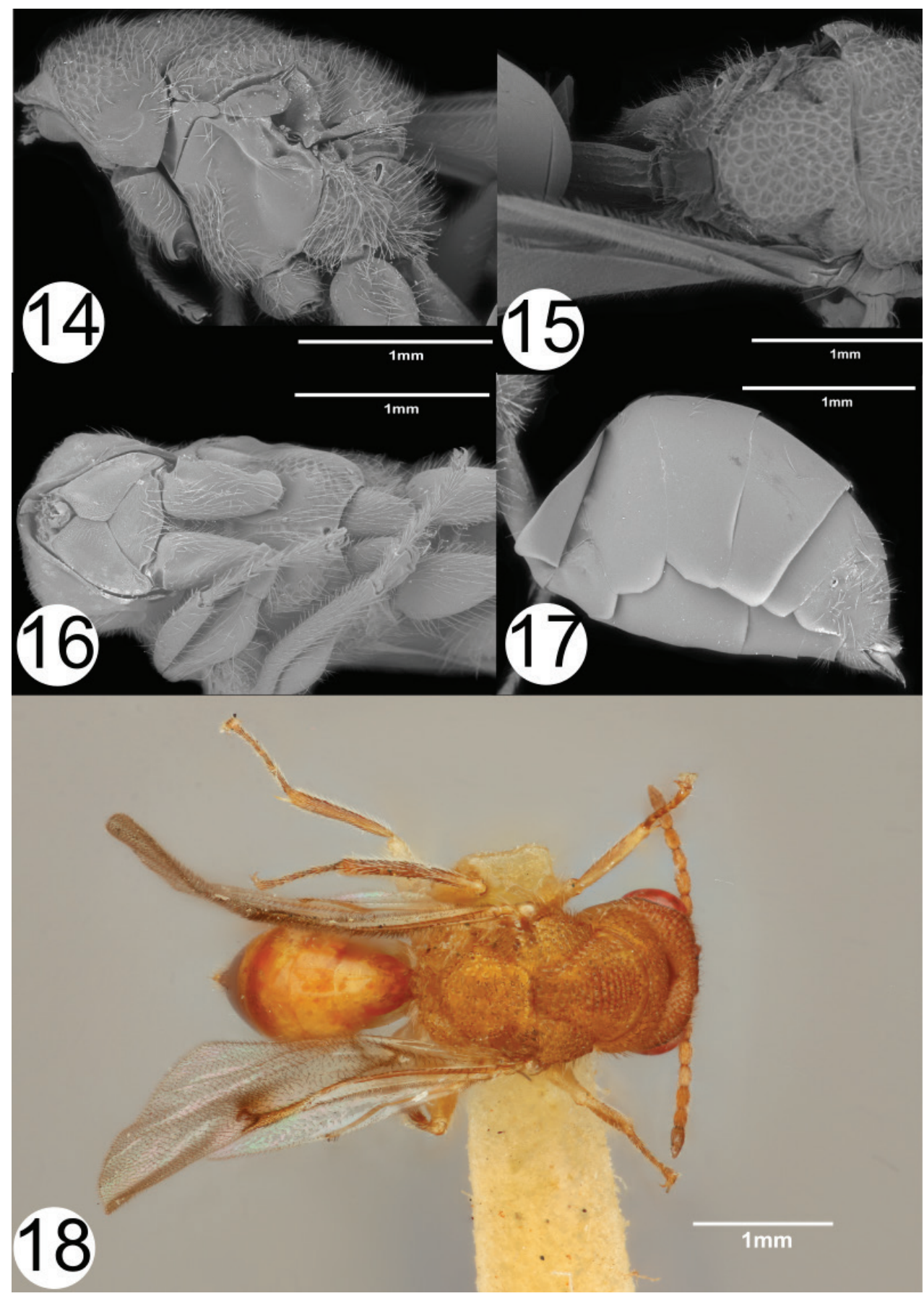

Figure 14-18. Kavayva bodoquenensis I 4 lateral view of male mesosoma I 5 dorsal view of male mesosoma $\mathbf{1 6}$ ventral view of mesosoma $\mathbf{1 7}$ ventral view of male metasoma $\mathbf{1 8}$ dorsal habitus of female specimen collected from Panama. 
(Figs 9, 25). Malar sulcus present, incomplete, reaching about $2 / 3$ of malar space. Malar space glabrous, smooth. Genal carina present. Toruli positioned parallel to the lower ocular line, diameter of torulus $3.3 \times$ that of the intertorular space. Intertorular space without projection between antennae (Fig. 9). Scrobal depression deeply excavated, converging ventrally in frontal view. Vertex areolate to umbilicate, anterior ocellus above scrobal depression. Scape with or without ventral plaque (females of Kavayva bodoquenensis). Antenna pedicel chalice-shaped, six funicular segments cylindrical with multiple irregular rows of longitudinal sensilla and whorls of setae, much shorter than its bearing segment, clava 2-segmented. Occiput concave, postgenal groove diverging, postgenal lamina present, subforaminal bridge ornamentation faint and inconspicuous (Fig. 10).

Wing. Forewing slightly infumated below marginal and stigmal vein, or forming a narrow band that curves slightly proximally and extending half way down the wing (Figs 7, 27). Costal cell, basal cell, and speculum (except for anterior edge) setose.

Mesosoma. Mesosoma umbilicate, $1.2-1.7 \times$ as long as broad. Notauli complete, shallow. Anterior pronotal carina widely interrupted. Femoral depression of mesopleuron weakly striate, mespeimeron smooth and shiny ventrally, bulging laterally (Fig. 14). Dorsellum carinae diverging. Propodeum in lateral view forming a $90^{\circ}$ angle with mesosoma, broadly delimited by carinae forming a hexagon with raised lateral corners (Fig. 15). Median furrow of propodeum concave and smooth, bordered laterally by irregular setose cells. Forecoxa without oblique groove (Fig. 16). All femora with distal lamella, forecoxa without oblique groove. Metacoxa bare laterally, metatibia densely setose.

Metasoma. Metasoma medially compressed, smooth, Gt4-Gt6 glabrous or setose. Petiole very short and not visible while specimen is intact (Figs 7, 22). Gaster S-shaped in lateral view, ovipositor angled at about $30^{\circ}$ dorsad of horizontal axis. Gt4 may be emarginate posteriorly in dorsal view.

Male. Color and sculpture as described similar to females. Ventral plaque on scape forming a projection on the inner face below the attachment point to pedicel (Figs 12, 13). Antennomeres with multiple rows of erect setae. Toruli positioned above the lower ocular line. Marginal vein swollen (Figs 8, 23). Gastral petiole striate dorsally, 1.5-1.7x as long as the length of metacoxa, smooth laterally.

Etymology. In the Guarani Native American language "Kavayva" means: "wasp of the fruit that gives seeds".

\section{Key to species of Kavayva}

1 Mesosoma uniform without black bands (Fig. 18), forewing with secondary wing band (Fig. 7), only males have ventral plaques on the scape.

Kavayva bodoquenensis sp. nov.

- $\quad$ Mesosoma with black bands (Fig. 24), forewing without secondary wing band (Fig. 27), both males and females have ventral plaques on the scape (Fig. 26) 


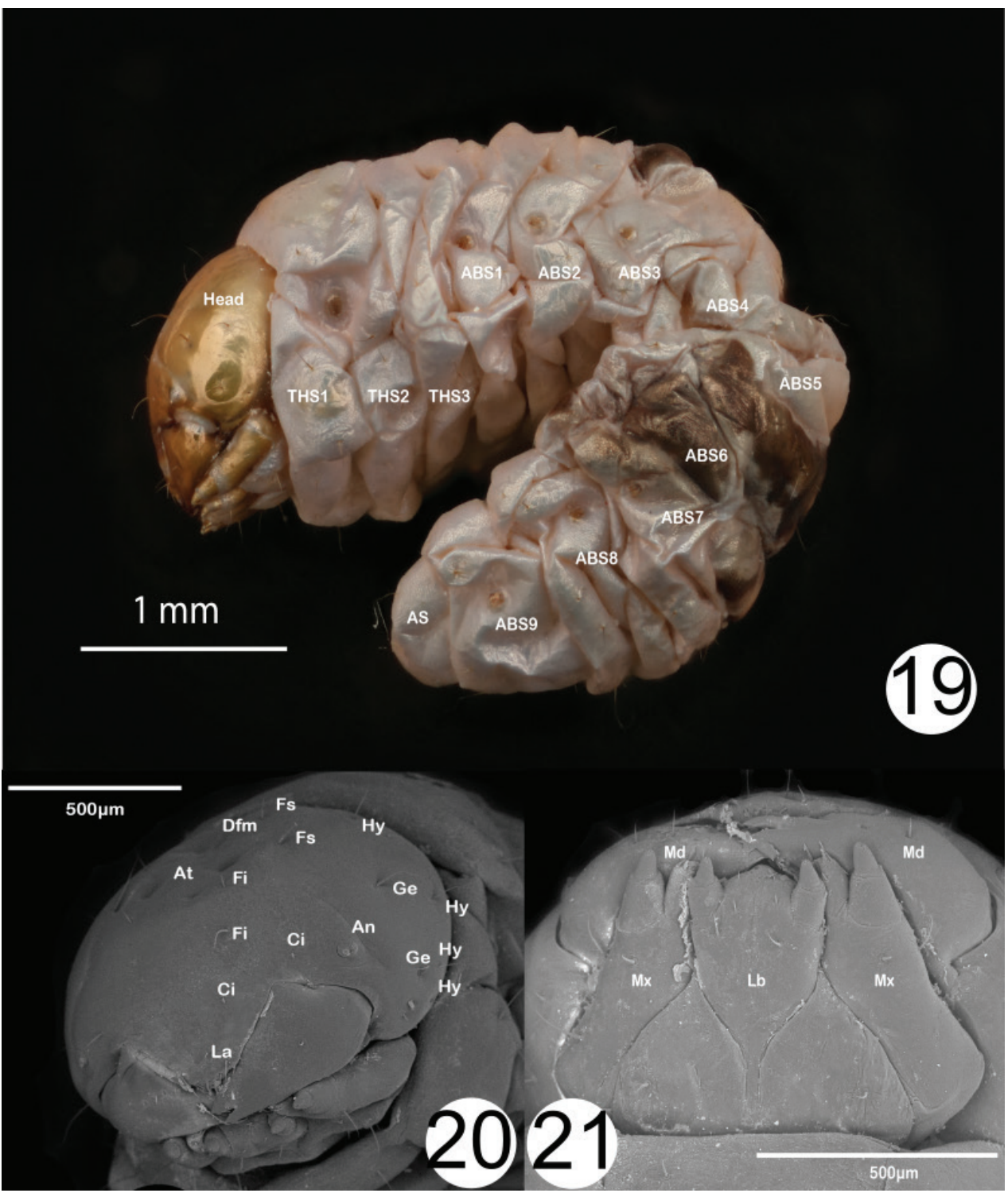

Figure 19-2 I. Kavayva bodoquenensis larva 19 lateral habitus, abdominal segment (ABS), anal segment (AS), thoracic segment (THS) 20 anterolateral view of head, antennae (An), anterior tentorial pit (At), clypeal setae $(\mathrm{Ci})$, cranial depression $(\mathrm{Dfm})$, interior frontal setae $(\mathrm{Fi})$, superior frontal setae $(\mathrm{Fs})$, anterior genal setae $(\mathrm{Ge})$, hypostomal setae (Hy), labral setae (La) $2 \mathbf{I}$ ventral view of head, labium (Lb), mandible (Md), maxilla (Mx).

Kavayva bodoquenensis Zhang, Silvestre, \& Gates, sp. nov.

http://zoobank.org/838C50D8-21F5-4092-AEDA-3E9A2675D005

Figs $7-21$

Material examined. Holotype BrazIL • [1F]; MS, Bonito, Serra da Bodoquena; 2106'56"S, 56³8'24"W; 8-29 May 2016; R. Silvestre leg.; ex fruit of Guarea kunthiana; 
USNMENT01788104. Paratypes BRAZIL • [9F, 9M]; same information as holotype; R. Silvestre and M. Scarpa leg.; USNMENT01788085-103 • [8F, 3M]; same information as holotype; UFGD Hymb00023-CH-00034-CH. Panama • [3F, 4M]; Arraiján; Sep. 1938; J. Zetek leg.; ex. fruit of Guarea guarea; No. 4279, Lot \# 88-17223; USNMENT01788078-084.

Diagnosis. Kavayva bodoquenensis can be distinguished from $K$. davidsmithi by the lack of black bands across mesosoma in dorsal view (Fig. 18), and the lack of ventral plaque in females.

Description. Holotype female. $6.5 \mathrm{~mm}$ in length.

Color. Yellow except malar sulcus, supraclypeal area, Gt3-syntergum of the metasoma (except for pairs of yellow patches dorsad of Gt 4 and Gt5), proximal half of femora and tibiae, wing veins, wing bands near basal setal line and marginal vein brown, edge of mandible, setae on head and mesosoma black and eyes pinkish red (Fig. 7).

Head. Quadrate with rounded corners, $1.2 \times$ as wide as high in frontal view, $2.5 \times$ as wide as long in dorsal view, areolate-rugose with setae (Fig. 11). Lower face weakly strigose, clypeus bilobed, mandible tridentate, supraclypeal area smooth, extending to the toruli. Malar sulcus present, incomplete, reaching to $2 / 3$ of malar space. Malar space glabrous, smooth. Genal carina present, smooth. Toruli positioned above lower ocular line about $1 / 3$ of the eye length, diameter of torulus $3.3 \times$ that of the intertorular space. Scrobal depression deeply excavated, converging ventrally in frontal view (Fig. 9). Vertex areolate-umbilicate, anterior ocellus above scrobal depression, ratios of POL:OOL:LOL 4:5:1. Scape without ventral plaque. Ratio of scape (minus radicle):pedicel:anellus:F1:F2:F3:F4:F5:F6:club as 14:3.3:1:6:6:6:5.3:4:7, pedicel chalice-shaped, funicular segments cylindrical with multiple irregular rows of longitudinal sensilla whorls of setae, much shorter than its bearing segment, clava 2-segmented. Occiput concave, postgenal groove diverging, postgenal lamina present, subforaminal bridge ornamentation faint and inconspicuous (Fig. 10).

Wing. Forewing infumated below marginal and stigmal vein, band narrow, curving slightly proximally, and extending half way down the wing. Basal and costal setal line also infumated. Ratio of marginal vein:postmarginal vein:stigmal vein as 1.5:1 (Fig. 7).

Mesosoma. Mesosoma umbilicate, $1.2 \times$ as long as broad. Notauli complete, shallow (Fig. 18). Anterior pronotal carina widely interrupted. Femoral depression of mesopleuron weakly striate, mesepisternum smooth (Fig. 14). Dorsellum carinae diverging. Propodeum in lateral view forming a $90^{\circ}$ angle with mesosoma, concave and smooth medially, bordered laterally by irregular, ridged, setose cells (Fig. 15). All femora with distal lamella.

Metasoma. Metasoma medially compressed, smooth, Gt4-syntergum setose. Petiole very short and not visible while specimen is intact (Fig. 7). Gaster S-shaped in lateral view, ovipositor angled at about $30^{\circ}$ dorsad to horizontal axis. Gt4 not emarginate posteriorly in dorsal view.

Male. $6.5 \mathrm{~mm}$. Scrobal depression black, ventral half of body whitish-yellow, wing vein amber, otherwise color and sculpture as described for females. Ventral plaque on scape forming a projection on the inner face below the attachment point to the pedicle (Figs 12,13). Antennomeres with multiple rows of erect setae. Gastral petiole striate dorsally, $1.5 \times$ as long as the length to metacoxa, smooth laterally (Fig. 17). 


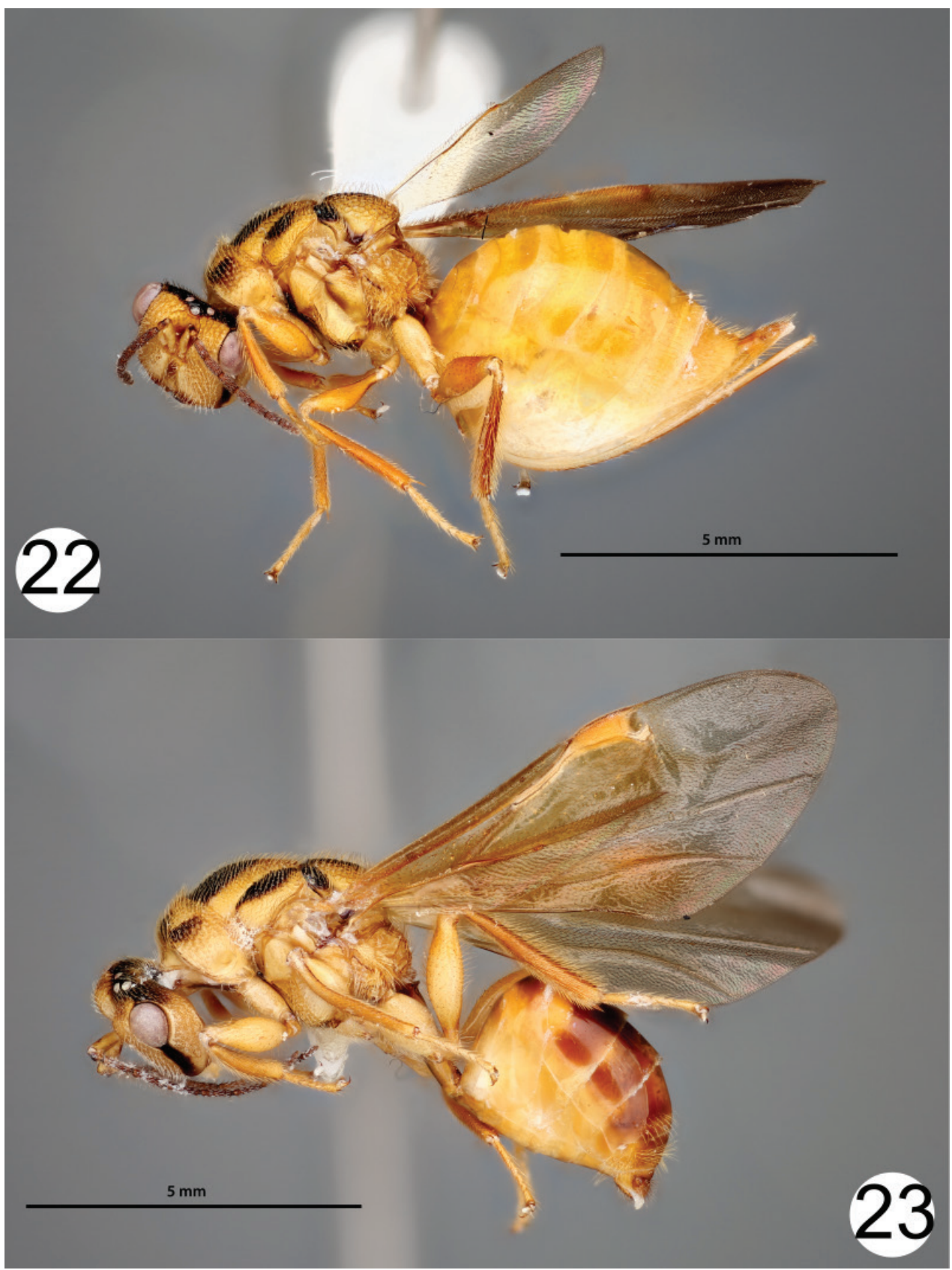

Figure 22-23. Kavayva davidsmithi lateral habitus $\mathbf{2 2}$ female $\mathbf{2 3}$ male. Photos by Cecilia Escobar.

Variation. Size ranges from 3.5-6.5 mm. Color ranges from mostly yellow to mostly black dorsally, mesepisternum can range from smooth to weakly striate.

Larva. Head amber-colored and body beige. Body length $4.7 \mathrm{~mm}$; width $1.7 \mathrm{~mm}$. Body C-shaped; 13 segmented (three thoracic, nine abdominal, and one anal segments); 


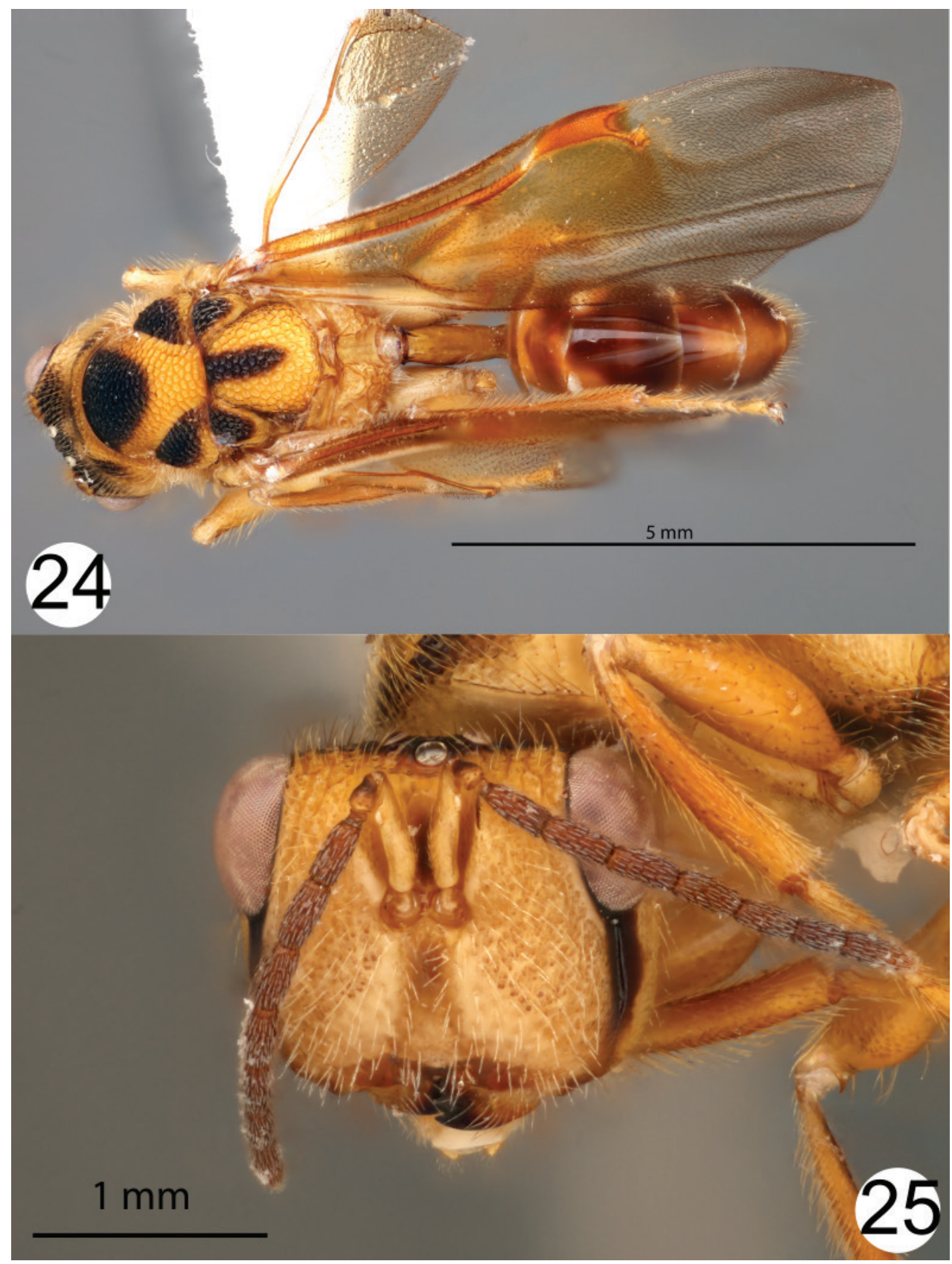

Figure 24-25. Kavayva davidsmithi $\mathbf{2 4}$ male dorsal habitus $\mathbf{2 5}$ frontal view of head. Photos by Cecilia Escobar.

tapering slightly posteriorly; no protuberance on body segments (Fig. 19). Head heavily sclerotized; antennae positioned ventrolaterally on the head, above the mandible, 1.29× as long as broad. Two pairs of superior frontal setae near the cranial depression, two pairs of interior frontal setae around anterior tentorial pits, two pairs of clypeal setae, 
antennae low and offset laterally, two pairs of genal setae, two pairs of labral setae, and four pairs of hypostomal setae (Fig. 20). Mandible narrowing apically, bidentate, with two pairs of sensilla. Underlip complex flat, with two pairs of setae on the median lobe (labium), and one on the lateral lobe (maxilla) (Fig. 21). Thoracic segments with two dorsal setae, one pair of pleural setae, one pair of lateral setae, and one pair of ventral setae. Abdominal segments with a single pair dorsal, pleural, and ventral setae. Anal segment with one pair of dorsal terminal setae, and ventral terminal setae present.

Biology. Associated with seeds of Guarea kunthiana and G. guarea = G. guidonia (Meliaceae).

Distribution. Brazil, Panama.

Etymology. Named in honor of the Serra da Bodoquena National Park, an environmental conservation unit in Mato Grosso do Sul, Brazil.

Remarks. The specimens collected from Panama are slightly smaller (3.5-5.5 mm) than those from Brazil (5.5-6.5 mm), and with lighter coloration on the wings and metasoma which could be the result of specimens being older (Fig. 18). We did not find any consistent morphological differences in either sex that reliably separate the Panama specimens from those collected in Brazil. Therefore we chose to group them all within $K$. bodoquenensis until fresh material can be collected for molecular work.

\section{Kavayva davidsmithi Zhang \& Gates, sp. nov.}

http://zoobank.org/50EAFCB5-FD0D-4FD5-9724-92A30E331ED8

Figs 1, 22-27

Material examined. Holotype Peru - [1F]; Manu National Park, Madre de Dios, Estación Biológica Villa Carmen; Trail 0; 14 Dec. 2013; 1253'41"S, 71²4'13"W; 650 m a.s.l.; A. L. Norrbom leg.; ex. seed in fruit of Guarea guidonia; 13-PE-46; MUSM. Paratypes PerU • [1F, 1M]; same information as holotype; USNMENT01788076, 077.

Diagnosis. Kavayva davidsmithi can be distinguished from $K$. bodoquenensis by the light infumation of the forewing and the absence of a secondary wing band on the basal setal line, extensive black bands across mesosoma in dorsal view, and the presence of ventral plaque on both sexes.

Description. Holotype female. $10.1 \mathrm{~mm}$ in length.

Color. Yellow except antennomeres, supraclypeal area light brown, tip of mandible, vertex, anterior half of occiput, malar sulcus, anterior half of dorsal and lateral pronotum, anterior half of midlobe of mesoscutum, lateral lobes of mesoscutum along the notauli, axillula, mediodorsal line on scutellum, ventral prepectus black, clypeus, wing vein, forewing below submarginal and marginal vein, femur, tibia amber and-eyes pinkish red (Fig. 22).

Head. Quadrate with rounded corners, $1.2 \times$ as wide as high in frontal view, 2.4x as wide as long in dorsal view, areolate-rugose with setae (Fig. 25). Lower face weakly strigose, clypeus bilobed, mandible tridentate, supraclypeal area slightly concave and extending to the toruli. Malar sulcus present, incomplete, reaching about $2 / 3$ of malar space. Malar space glabrous, smooth. Genal carina present. Toruli positioned above the 


\section{6}

\section{$1 \mathrm{~mm}$}

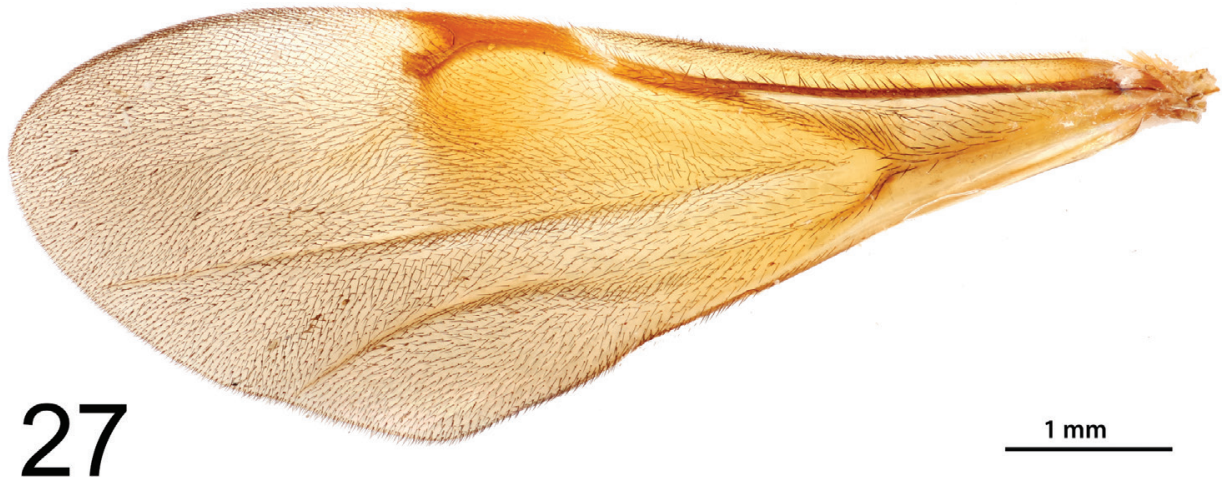

Figure 26-27. Kavayva davidsmithi $\mathbf{2 6}$ male head and antennae $\mathbf{2 7}$ female forewing. Photos by Cecilia Escobar.

lower ocular line about $1 / 3$ of the eye length, diameter of torulus $3.3 \times$ that of the intertorular space. Scrobal depression deeply excavated. Vertex areolate, anterior ocellus above scrobal depression, ratios of POL:OOL:LOL equal to 3:4:1. Ventral plaque on scape forming a projection on the inner face below the attachment point to the pedicle. Ratio of scape (minus radicle):pedicel:anellus:F1:F2:F3:F4:F5:F6:club as 10:2.7:1:5.7: 6.3:6.3:5.7:5:4.7:6.7, pedicel chalice-shaped, funicular segments with multiple irregular rows of longitudinal sensilla whorls of setae, much shorter than its bearing segment, clava 2-segmented (Fig. 25). Postgenal lamina present. 
Wing. Forewing infumated half way down the wing below the submarginal and marginal vein, not exceeding stigmal vein. Ratio of marginal vein:postmarginal vein:stigmal vein as 2.3:1.2:1 (Fig. 27).

Mesosoma. Mesosoma umbilicate, $1.7 \times$ as long as broad. Notauli complete, shallow (Fig. 26). Anterior pronotal carina interrupted. Femoral depression of mesopleuron weakly striate, mesepimeron smooth and shiny ventrally, bulging laterally (Fig. 22). Dorsellum carinae diverging. Propodeum in lateral view forming a $90^{\circ}$ angle with mesosoma, broadly delimited by carinae forming a hexagon with raised lateral corners. Median furrow of propodeum concave and smooth, bordered laterally by irregular setose cells. All femora with distal lamella.

Metasoma. Metasoma medially compressed, smooth, Gt6-syntergum setose. Gaster S-shaped in lateral view, ovipositor angled at about $30^{\circ}$ dorsad to horizontal axis (Fig. 22). Gt4 emarginate posteriorly in dorsal view.

Male. $9.4 \mathrm{~mm}$. Scrobal depression black, otherwise color and sculpture as described for female (Fig. 23). Antennomeres with multiple rows of erect setae and about $1.4 \times$ as long as width of segment (Fig. 26). Gastral petiole length in dorsal view about 2.8× as long as its greatest width, $1.7 \times$ as long as the length to metacoxa, smooth (Fig. 23).

Variation. The coloration on the vertex and occiput can be confluent or disconnected.

Biology. Associated with seeds of Guarea guidonia (Meliaceae).

Distribution. Manu National Park, Peru.

Etymology. Patronym honoring David Smith for his decades of devotion to Hymenoptera and improvement of the Smithsonian's National Insect Collection.

\section{Discussion}

The new genus Kavayva is only found associated with the seeds of Meliaceae, which represent a new plant family association within Eurytomidae, and the fourth genus associated with seeds in the Neotropics. Based on the upcoming phylogenomic study of Eurytomidae (Zhang et al., in prep.), all of these phytophagous genera are only distantly related to each other, meaning that phytophagy has evolved multiple times within Eurytomidae. While addressing the evolutionary relationships is beyond the scope of this paper, we provide a brief literature review of the morphological characters in order to distinguish these four genera (Table 1). The ventral plaque that is present in all known species of Kavayva is also present in some species of Prodecatoma (e.g., P. diospyri), although the latter can be easily distinguished by the presence of a large intertorular projection and the hyaline forewing. Bephratelloides have a stigmated wing and a minute intertorular projection similar to Kavayva, but lack the ventral plaque. Finally, Eurytoma werauhia differs from Kavayva in being mostly black in color, and lacks the ventral plaque.

Given the morphological conservatism within Eurytomidae, it is not surprising that a combination of morphological characters is needed to distinguish these four genera of eurytomids. We hope this study will aid in the discovery of additional Kavayva specimens and records, as their host plant Guarea can be found from northwestern Mexico down to northern Argentina (Pennington and Clarkson 2013). 


\section{Acknowledgements}

We thank Bhrenno Maykon Trad, Vander Carbonari, Vinícius Marques Lopez for helping us in laboratory work/photos, and to Instituto Chico Mendes de Biodiversidade-ICMBio from Bonito MS for field collection permissions under SISBIO number 3266-1 date: Oct/06/2011. We would also like to thank Allen Norrbom for providing specimens as bycatch for the USDA Farm Bill project "Enhancement of Fruit Fly Larvae Identification and Taxonomy" (Project Coordinator G.J. Steck, ADODR Norman Barr; project numbers 3.0342 (2012) and 13-8131-0291-CA (2013). Collections in Peru were made through Asociación para la Conservación de la Cuenca Amazónica (ACCA) and its U.S. partner, the Amazon Conservation Association (ACA), with permission of Director General Forestal y de Fauna Silvestre (Resoluciones Directorales No. 0614-2011-AG-DGFFS-DGEFFS). USDA is an equal opportunity employer and provider. Mention of trade names herein is for informational purposes only and does not reflect endorsement by USDA. YMZ is supported by Oak Ridge Institute for Science and Education (ORISE) fellowship.

\section{References}

Castañeda-Vildózola A, Nava-Díaz C, Váldez-Carrasco J, Ruiz-Montiel C, Vidal-Hernández L, Barrios-Matias S (2010) Distribution and host range of Bephratelloides cubensis Ashmead (Hymenoptera: Eurytomidae) in México. Neotropical Entomology 39(6): 1053-1055. https://doi.org/10.1590/S1519-566X2010000600034

Castañeda-Vildózola A, Nava-Díaz C, Franco-Mora O, Lomeli-Flores JR, Peña JE (2011) Diospyros digyna (Ebenaceae): a new host record for Bephratelloides ablusus (Hymenoptera: Eurytomidae) in Mexico. Florida Entomologist 94(4): 1071-1072. https://doi.org/10.1653/024.094.0451

Chang PRA (1998) Descripción de Bephratelloides duguetiphagus n. sp. (Hymenoptera: Eurytomidae) criados de frutos de Duguetia panamensis Standl. (Annonaceae). M. Sc. Dissertation, Universidad de Panamá, Panamá.

DalMolin A, Melo GA, Perioto NW (2004) New species of Prodecatoma (Hymenoptera, Eurytomidae) associated to galls in fruits of two species of Psidium L. (Myrtaceae), with comments on Prodecatoma spermophaga Costa-Lima. Revista Brasileira de Entomologia 48(4): 519-528. https://doi.org/10.1590/S0085-56262004000400015

Folmer O, Black M, Hoeh W, Lutz R, Vrijenhoek R (1994) DNA primers for amplification of mitochondrial cytochrome c oxidase subunit I from diverse metazoan invertebrates. Molecular Marine Biology and Biotechnology 3: 294-299.

Gates MW, Cascante-Marin A (2004) A new phytophagous species of Eurytoma (Hymenoptera: Eurytomidae) attacking Werauhia gladioliflora (Bromeliales: Bromeliaceae). Zootaxa 512: 1-10. https://doi.org/10.11646/zootaxa.512.1.1

Gates MW, Pérez-Lachaud G (2012) Description of Camponotophilus delvarei, gen. nov. and sp. nov. (Hymenoptera: Chalcidoidea: Eurytomidae), with discussion of diagnostic characters. Proceedings of the Entomological Society of Washington 114: 111-124. https://doi. org/10.4289/0013-8797.114.1.111 
Gibson GAP (1997) Morphology and terminology. In: Gibson GA, Huber JT, Woolley JB (Eds) Annotated keys to the genera of Nearctic Chalcidoidea (Hymenoptera). NRC Research Press, Ottawa, ON, 16-44.

Grissell EE, Schauff ME (1990) A synopsis of the seed-feeding genus Bephratelloides (Chalcidoidea: Eurytomidae). Proceedings of the Entomological Society of Washington 92: $177-187$.

Grissell EE, Foster MS (1996) A new Bephratelloides (Hymenoptera: Eurytomidae) from seeds of Cymbopetalum (Annonaceae) in Mexico. Proceedings of the Entomological Society of Washington 98: 256-263.

Harris RA (1979) Glossary of surface sculpturing. Occasional Papers in Entomology 28: 1-31. Henneicke K, Dawah HA, Jervis MA (1992) Taxonomy and biology of final-instar larvae of some Eurytomidae (Hymenoptera: Chalcidoidea) associated with grasses in the UK. Journal of Natural History 26(5): 1047-1087. https://doi.org/10.1080/00222939200770621

Hernández-Fuentes LM, Bautista-Martínez N, Carrillo-Sánchez JL, Sánchez Arroyo H, UríasLópez MA, Salas Araiza MD (2008) Control del barrenador de las semillas, Bephratelloides cubensis Ashmead (Hymenoptera: Eurytomidae) en guanábana, Annona muricata L.(Annonales: Annonaceae). Acta Zoológica Mexicana 24(1): 199-206. https://doi. org/10.21829/azm.2008.241631

Lorenzi H (2002) Árvores brasileiras: manual de identificação e cultivo de plantas arbóreas nativas do Brasil, $2^{\text {nd }}$ edn. Instituto Plantarum de Estudos da Flora Ltda, Nova Odessa, SP, Brazil, 248 pp.

Lotfalizadeh H, Delvare G, Rasplus J-Y (2007) Phylogenetic analysis of Eurytominae (Chalcidoidea: Eurytomidae) based on morphological characters. Zoological Journal of the Linnean Society 151: 441-510. https://doi.org/10.1111/j.1096-3642.2007.00308.x

Moura JIL, Sgrillo RB, Sgrillo KR, Vilela EF, Bento JMS (2006) Uso de fêmeas virgens na coleta massal de Bephratelloides pomorum (Fab.) (Hymenoptera: Eurytomidae) em Annona muricata L. (Annonaceae). Manejo Integrado de Plagas y Agroecología 77: 78-81.

Peña JE, Bennett FD (1995) Arthropods associated with Annona spp. in the Neotropics. Florida Entomologist 78(2): 329-349. https://doi.org/10.2307/3495906

Pennington TD, Clarkson JJ (2013) A Revision of Guarea (Meliaceae). Edinburgh Journal of Botany 70(2): 179-362. https://doi.org/10.1017/S0960428613000036.

Roskam JC (1982) Larval characters of some eurytomid species (Hymenoptera, Chalcidoidea). Proceedings Koninklijke Nederlandse Akademie van Wetenschappen 85: 293-305.

Ruiz-Montiel C, González-Pérez JS, Valdez-Carrasco J, Lomelí-Flores JR, Gates MW, FrancoMora O, Castañeda-Vildózola Á (2021) Correcting the identity of a eurytomid wasp associated with Black Sapote fruits in Mexico with new distributional records and notes on its biology, Proceedings of the Entomological Society of Washington 123(2): 437-442. https://doi.org/10.4289/0013-8797.123.2.437

Short JRT (1952) The morphology of the head of larval Hymenoptera with special reference to the head of the Ichneumonoidea, including a classification of the final instar larvae of the Braconidae. Transactions of the Royal Entomological Society of London 103(2): 27-84. https://doi.org/10.1111/j.1365-2311.1952.tb02262.x 
Souza LA, Moscheta IS, Mourão KSM, da Rosa SM (2002) Morfo-anatomia da flor de Guarea kunthiana A. Juss. e de Guarea macrophylla Vahl.(Meliaceae). Acta Scientiarum. Biological Sciences 24: 591-600. https://doi.org/10.4025/actascibiolsci.v24i0.2372

Wenny DG (1999) Two-stage dispersal of Guarea glabra and G. kunthiana (Meliaceae) in Monteverde, Costa Rica. Journal of Tropical Ecology 15(4): 481-496. https://doi.org/10.1017/ S0266467499000966

Yirgu A, Delvare G (2019) First report of Paradecatoma bannensis Masi (Hymenoptera, Eurytomidae) as seed parasite of Cordia africana in Ethiopia. Phytoparasitica 47(5): 647-657. https://doi.org/10.1007/s12600-019-00763-w 